\title{
Towards a better understanding of the today French torrents management policy through a historical perspective
}

\author{
Simon Carladous ${ }^{1,2,3, a}$, Guillaume Piton ${ }^{1}$, Alain Recking ${ }^{1}$, Frédéric Liébault ${ }^{1}$, Didier Richard ${ }^{1}$, Jean Marc Tacnet ${ }^{1}$, Damien \\ Kuss $^{4}$, Félix Philippe ${ }^{1}$, Yann Quefféléan ${ }^{5}$ and Olivier Marco ${ }^{5}$ \\ ${ }^{1}$ Université Grenoble Alpes, Irstea, UR ETGR, 2 rue de la Papeterie-BP 76, F-38402 St-Martin-d'Hères, France \\ ${ }_{2}^{2}$ AgroParisTech, Paris Institute of Technology for Life, Food and Environmental Sciences, Paris, France \\ ${ }^{3}$ Ecole Nationale Supérieure des Mines, Saint-Etienne, France \\ ${ }^{4}$ Office National des Forêts - Service Restauration des Terrains de Montagne de I'Isère, Grenoble, France \\ ${ }^{5}$ Office National des Forêts- Département risques naturels, Grenoble, France
}

\begin{abstract}
Protective measures against torrential floods and lowlands' floods have been set up since the $19^{\text {th }}$ century in mountainous areas. To help decide on maintenance of numerous existing structures, a better understanding of their objectives and technical functions is needed. Nevertheless, that remains tricky in torrent management context, due to several changes for more than 150 years, either in terms of natural torrential risk (e.g. land-use changes), scientific understanding of complex phenomena (e.g. hillslope-streambed coupling), understanding of protective actions (e.g. influence on the sediment transport), laws and regulations (e.g. increasing of multi-issues problems), and management organization. An archive analysis was done to bridge this gap. Pioneering books of the late $19^{\text {th }}$ century have been reviewed to sum up local and regional objectives of protective measures, but also their technical functions on torrential processes. We recall the first RTM laws and their implementation conditions. An analysis of laws, regulations and public management evolutions helps to understand risk management changes, influencing current maintenance decisions. We finally synthesize the objectives and local technical functions of protective measures. We propose some elements to go towards a quantification of risk reduction even if it remains a key challenge.
\end{abstract}

\section{Introduction}

In France, floods are the most economic damaging natural phenomena, excluding storm and hailstorm [1]. They are slow in lowland rivers (with slopes lower than $1 \%$ ) but rapid in torrential rivers (slopes between 1\% and $6 \%$ ) and torrents (slopes upper than $6 \%$ ) [2]. Flood hazards exist in $92 \%$ of local municipalities within the 11 mountainous French departments (6 in the Alps, 5 in the Pyrenees) [3].

Sediment transport makes torrential floods different from lowland ones. Suspension or bed-load processes carry out sediments in all rivers. Hyper-concentrated bedload is specific to torrential rivers and torrents, while debris flows only occur in torrents [2]. In mountainous areas, torrential processes impact housing, industrial and agricultural areas. They can also lead to indirect damage by cutting communication and resources networks [4] (Fig. 1).

Increase of the risk due to sediment load was conceptualized as soon as the $19^{\text {th }}$ century and is still an active topic of research. A French national management of mountainous areas, called RTM (Restoration of Mountainous Areas), has been engaged for more than 150 years mainly seeking to curtail sediment production in torrent headwaters (active protection). More than 100000 check dams were built within almost $3800 \mathrm{~km}^{2}$ of RTM forests [5]. The public National Forestry Office (ONF) manages the latter taking into account their protective role. The French government owns their civil engineering structures and decides their maintenance priorities. The technical work is done by the ONF-RTM service.

Outside public forests, local municipalities lead their own protection strategy to protect elements within torrential hazard prone areas. It mainly consists in direct fan protection, also called passive structures in France (dikes, sediment traps, etc.) (Fig. 1). Their exposure and vulnerability are controlled through land use plans. Private experts and the ONF-RTM help local municipalities to manage the establishment of such plans.

Within a watershed, decision-makers must rank priorities between several actions (maintenance, new investment, several technics) (Fig. 1). They may take into account several criteria such as risk reduction and cost, which help to assess efficiency of actions [6]. In practice, protection works' effectiveness remains poorly taken into account in land use plans [7]. To make a proper decision, the effect of structures on hazard reduction must be assessed, which remains challenging [6-8]. This also implies specifying the protective function and the corresponding structural and functional capacity of structures $[6,9]$.

\footnotetext{
${ }^{\mathrm{a}}$ Corresponding author: simon.carladous@irstea.fr
} 


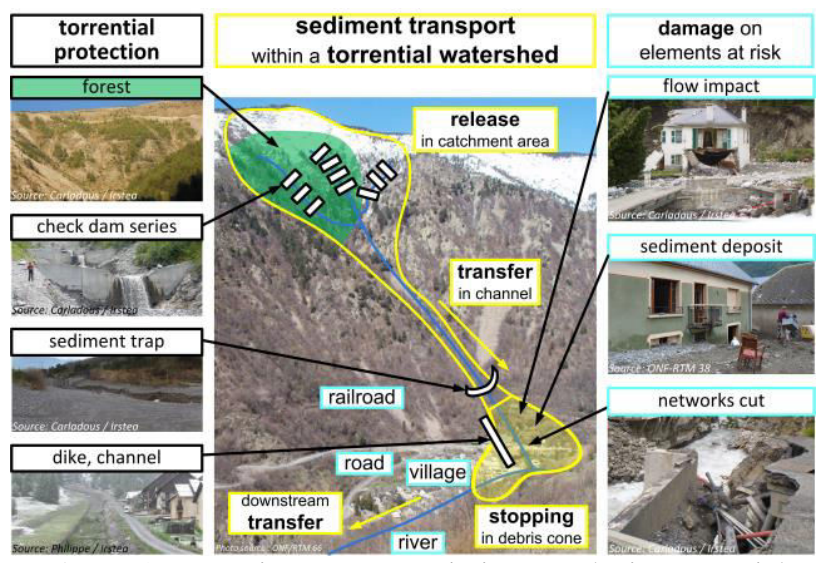

Figure 1. Protective structures aiming at reducing potential damage on elements at torrential risk within a watershed.

Such current decisions depend on previous decisions based on risk reduction objectives. For more than 150 years, the decision context timely and spatially changed along with natural torrential hazard (climatic, environmental changes), elements at risk (socioeconomic changes), scientific understanding (torrential processes, effect and structural stability of protections), laws and regulations (multi-issues), and management organization [10,11]. Knowing this, one can legitimately question if past choices match with current problems and stakes. One can also analyze the morphological change due to protective structures and what consequences their voluntary abandonment or their destruction could lead.

Analyzing the torrential hazard reduction is not trivial $[6,8]$. The torrential dynamic is complex, e.g. actions on torrent beds induce lower bank and hillslope erosions [12]. A simple check dam, or a check dam series, can thus have several different functions that affect torrential floods and debris-flows processes. Listing these potential functions would be technically helpful for practitioners [8].

Therefore, this paper aims to bring a better understanding of objectives, functions and management conditions of torrential protective measures. Changes of the French management of torrents could be described through a chronological analysis of the RTM management: the period of tests (1860-1882), the "Golden Age" (1882-1914), the maintenance time (19141940), the decline (1940-1980), and the re-founding time (since 1980) [10]. However, we propose in this paper another thematic reading grid to overview at the national scale changes in decision context, mitigation objectives, scientific and technical understanding.

For this purpose, this paper first introduces more than 150 years of general change in mountainous natural risk, in scientific understanding of related torrential processes and in protection technics development. Then, it details regulatory and management evolution. We finally extract main objectives and functions of torrential protective structures which could currently help to state on maintenance actions. To conclude, we discuss how to use it in a quantification process of risk reduction needed to support decision in this field [13].

\section{Torrential risk and protection development since the $19^{\text {th }}$ century}

This part first describes torrential risk evolution over time in mountainous areas, through hazard and potential damage analysis. Then, it develops the understanding of torrential processes and related protection such as check dams. The Figure 2 synthesizes main ideas.

\subsection{Natural risk in French mountains}

\subsubsection{Potential damage change}

The population peak in French mountainous areas was reached in the $19^{\text {th }}$ century. The first industrial revolution implied an industrial development of lowland as well as mountain valleys, nearby streams and torrential streams. Following, road and railway networks were significantly developed down the valley along main torrential rivers and crossing numerous torrents [14].

From the 1880s to the beginning of the $20^{\text {th }}$, the second industrial revolution was characterized by the use of new energy sources such as electricity, gas and petrol. Energy transport networks, hydroelectricity production and new roads and railways were thus developed in mountain valleys. On the contrary, industries were concentrated in lowlands. As a severe agricultural crisis occurred in the 1880s, the rural depopulation began [14].

The $1^{\text {st }}$ World War (WWI) (1914-1918) accelerated this trend and triggered a quick rural exodus [15], which continued to increase after the $2^{\text {nd }}$ World War (WWII) (1939-1945) [16]. Thus, agricultural pressure on land use decreased in mountainous areas since the WWI. At local scale, this induced spontaneous revegetation and reforestation over headwaters. This also led to a decrease of cultivated lands nearby torrents. On the contrary, at a regional scale, population and industries grew nearby lowland rivers.

Since the 1960s, population at risk in mountains has switched. A national "Snow Plan" was engaged in 1964 in order to promote the development of massive winter tourism. At the same time, traditional permanent farmers left valleys, inducing a general population shrinking in some remote areas, such as in the southern pre-Alps [17]. In other mountain valleys, such as in the northern Alps, the development of winter, as well as summer tourism industry, induced a high economic and urban development. Newcomers, including retired people, thus came to live in peri-urban locations [18]. With a decreasing natural hazard awareness, dwellings and industries were set up right on the alluvial fans of torrents $[18,19]$. Combined with a greater vulnerability of these new populations, potential damage increased in many mountain valleys [10]. Moreover, transport networks cutting became very damageable with regard to touristic displacements and commuting of peri-urban populations, the latter working in towns. 


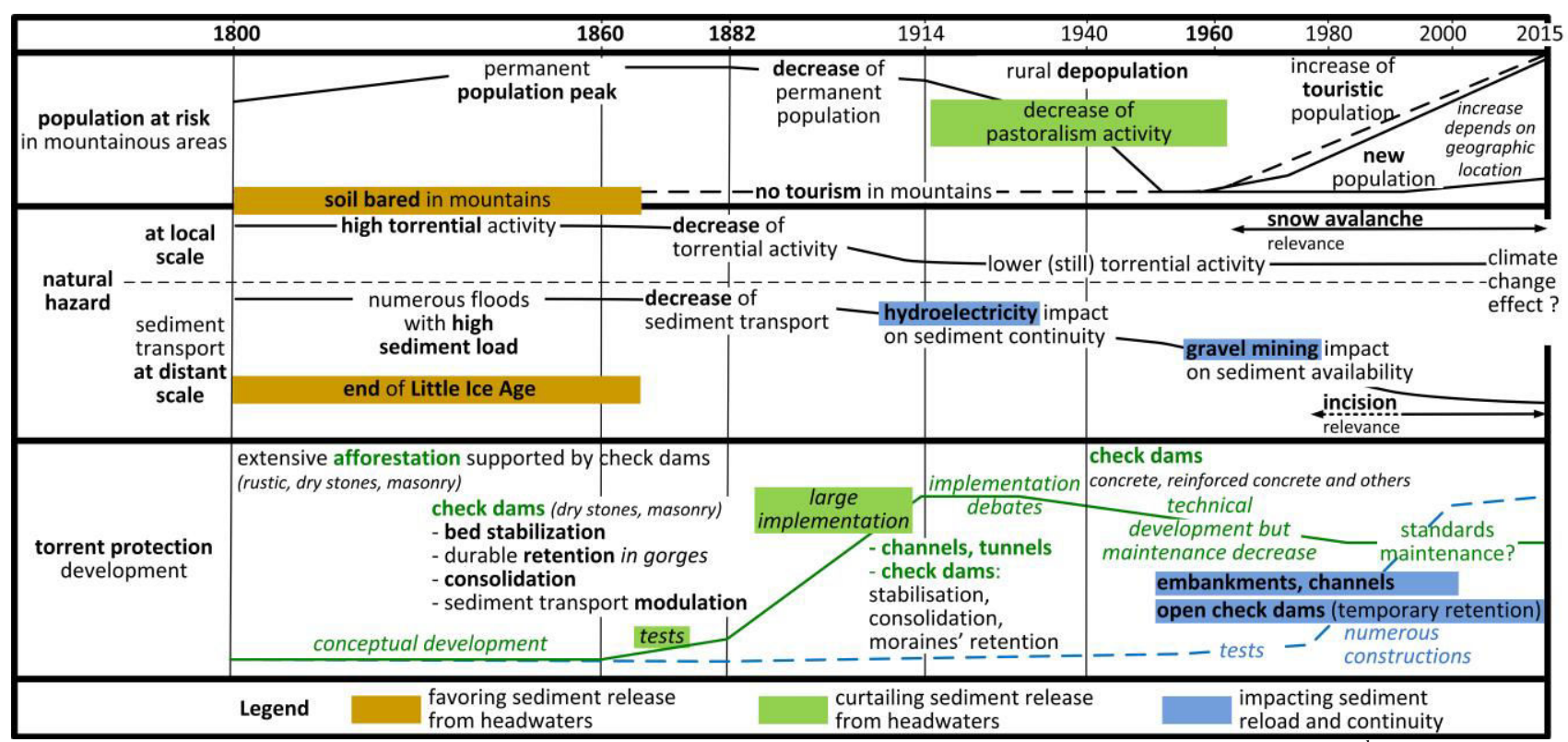

Figure 2. Torrential risk evolution in mountainous areas and development of adapted protection since the $19^{\text {th }}$ century.

\subsubsection{Natural hazard change}

The beginning of the $19^{\text {th }}$ century corresponds to the end of the Little Ice Age, a cold period with a high sediment transport and hydrologic activity [20]. As a distant consequence, aggradation and widening of some rivers was observed [21], and stream beds and fluvial activity areas were larger than today. Flood thus regularly damaged elements at risk [22]. Moreover, French forests were intensively exploited to produce timber (housing, navy, and mining) and firewood for local use. Lands nearby headwaters were mainly agriculturally used for pastoralism or local subsistence crops, which implied forest clearing and bare soils, sensitive to erosion [14]. Overall, torrential hazard at local or regional scale was related to an excess of sediment production from the headwaters.

The effect of the end of the Little Ice Age decreased from the second part of the $19^{\text {th }}$ [23]. The natural torrential activity generally shrank in mountainous areas. The reforestation and revegetation also helped to curtail sediments in headwaters. As a result, sediment transfer to downstream main-stems decreased.

During the $20^{\text {th }}$ century, the hydroelectricity development was based on water storage dams in large rivers but also on derivation dams in torrential rivers and torrents. Those dams inevitably stopped natural sediment transport and led sediment storage. During this period, the pastoralism activity decrease on hillslopes, due to rural depopulation favoring a natural revegetation. Industrial instream gravel mining started during the 1950 s to support concrete buildings and road network development. It rapidly increased during the 1970s-1980s [24]. At the same time, embankments were built to protect the increasing population over alluvial fans. Those protections have thus limited the sediment recharging by torrent shifting.
As a consequence of those changes of natural processes and human activity, the stress on the sediment transport continuity exploded during the $\mathbf{2 0}^{\text {th }}$ century [23]. At a local scale, torrential floods and debris flows always endangered elements at risk nearby torrents and damageable downstream incision appeared.

Snow avalanches can also bring materials from release zones until torrent streams. In order to limit such incomes, protective walls in dry stones were built in release zones from the $19^{\text {th }}$ [25]. Moreover the significance of snow avalanches in natural risk management in mountainous areas has increased with the population change since the 1960s [10], even if there was no change in its general activity.

Currently, understanding climate change impacts on mountainous natural hazards is a key issue. That must hopefully help to get a better comprehension of changes in natural phenomena activity (either in frequency and intensity), especially with regard to all complex transfer processes between torrential hazards and related phenomena such as erosion, landslides, rock falls, debris avalanches, and snow avalanches.

\subsection{Development of a scientific understanding of torrential processes}

\subsubsection{Main steps of French torrential process understanding}

From the 15th century, European countries and especially Italy have seen the emergence of a scientific hydraulic community. From there, Da Vinci, Castelli and their followers influenced French authors. During the first part of the $19^{\text {th }}$ century, some of the latter, gathered in a group later called "the Foresters" [14], warned about increase of erosion processes due to forest clearing [27]. They argued that mountainous areas 
produced more sediments than expected under "natural" conditions, increasing torrential activity but also floods in lowland rivers. Even if the latter was early discussed $[28,29]$, they developed a geomorphic understanding of torrential dynamics and put in light the role of sediment production in natural hazard processes.

In 1797, Fabre highlighted differences between rivers and torrents: the former would have bed-slopes that balance stream power and bed-roughness; the latter wouldn't be at the equilibrium because of a lack of time to reach it [30]. In 1841, Surell identified three main natural parts of the torrent catchment: the headwater basin with sediment production, the gorges with water and sediments transfer, and the fan with materials deposition and high morphologic activity [27] (Fig. 1). In 1848 , Gras conceded that torrential activity was related to gullying systems in headwaters but he added that landslides and cliffs can erratically supply extinguished torrents [31].

In 1850, Gras studied the hydraulic mechanisms of gravel entrainment, transport capacity and deposition conditions. He also differentiated the "transport en masse" (i.e. debris flows and debris floods) from the partial transport process (i.e bed-load) [32]. Followed by Breton, they pointed out between 1857 and 1867 the possible lack of sediment transport between torrent fans and river systems [21,33].

In 1882, Demontzey proposed a classification of torrents according to the nature of processes causing sediment supply in the headwaters: scouring torrents with gullying systems, 'claps torrents' with cliffs and glacial torrents with glaciers and moraines [34]. In 1900, Kuss focused on debris flow over proglacial torrents [35], as well as on torrents characterized by landslides and rockfalls in their headwaters [36].

At the beginning of the $20^{\text {th }}$ century, French forestry engineers such as Mougin and Bernard, understood that torrential hazard assessment needed a detailed study of torrents based on event feedbacks. They published several books of pure historical analysis registering damaging events [37-39]. In 1927, Bernard detailed the knowledge on forestry, geomorphic, hydrologic and hydraulic calculation to implement study at the torrential watershed scale [40].

Since the 1970s, the sediment continuity process has been progressively highlighted by stream bed incision problems [41]. Then it has been shown that incision can be damageable for protective infrastructures and for river ecosystems [42,43]. It thus recently became an operational management subject: at local scale, torrential risk is related to an excess of sediment load; at a larger scale, it can be linked to a lack of sediment load.

Risk quantification became of scientific interest in mountainous areas from the 1970s. Hazard quantification and understanding was needed for risk mapping and decision on protection actions $[44,45]$. Key scientific works were then published at the beginning of the 1990s to better understand and quantify the different torrential processes linked to sediment transport processes $[2,46]$.

\subsubsection{Development of understanding of torrential structures' protective roles}

In 1797, in order to limit sediment load, Fabre proposed to build dikes and bank protection downstreams and to afforest headwaters. Small check dams made of wood logs could support the latter [30]. In the same way, Surell proposed in 1841 the same works to stabilize torrents, making possible to plant trees and bushes on their banks [27].

Between 1850 and 1867, Gras and Breton focused on high check dams' design [21,32,33]. In general, they agree with the long-term effectiveness of headwaters' afforestation to reduce sediment load from gullying systems. They also advocated that check dams could obtain a short-term mitigation effect, which could complete afforestation in highly unstable watersheds and could regulate sediments in torrent beds. They theorized three functions of check dams [8]. Retention check dams would be built to trap definitively sediments, especially within gorges or over the bottom part of headwaters. Consolidation dams would aim to create a thick sediment layer to protect cliff-toes. Finally, sediment transport regulation check dams may be used to dose sediment transport in order to limit the "transport en masse" phenomena. Moreover, Gras also theorized that open check dams, equipped with slots, would have a dosing effect [21].

Between 1860 and 1882, forestry officers aimed to extensively afforest mountainous areas. Some local initiatives showed that stabilizing torrents through check dams made of wood or dry stones was first needed [11]. The 1882 Demontzey's guideline [34] gathered feedbacks and was the starting point of the "golden age" of RTM works in torrent headwaters (1882-1914) [10] (Fig. 3). From his empirical forester point of view, check dams were built to stabilize torrent bed, diminish its slope and widen the bed to prevent its incision and the related hillslopes' destabilization. Stone check dams were built in big torrents, while smaller counter check dams and ground sills made of living wood were set up upstream parts. Once the objective of stabilizing forests would be achieved, some structures could be abandoned. In torrents with cliffs, glaciers and moraines in the headwaters, retention check dams were recommended in last resort near the fan apex, if structures set over the headwaters were not sufficient. Demontzey gave also some details on drainage technics dedicated to landslide stabilization. In 1891, Thiéry transposed hydraulic and sediment transport calculations to mountain streams and introduced dam stability calculations [47].

During this period, other correction works were designed: flushing tunnels to drain glaciers [38], retention dam at the lower part of moraines and colluvial materials [35], landslide toe by-pass using derivation channels or tunnels [48] and consolidation check dams [36]. All these structures in dry stone or masonry were made using affordable work forces from rural population in precarious safety conditions. 
Debates occurred during the first part of the $20^{\text {th }}$ century. Within the Water and Forestry Administration (WFA), before the WWI, they highlighted that afforestation objective could be achieved with a social (main objective was to limit rural depopulation) or an authoritarian (main objective was to afforest to protect) point of view [11,14]. Debates continued in the "Revue de Géographie Alpine" especially between the geographer Lenoble and the forestry engineer Mougin. The point of anthropic deforestation in mountainous areas at the beginning of the $19^{\text {th }}$ century, which justified the RTM policy, was discussed [38,49]. As a conclusion, we can say that torrential activity and later revegetation had several human and natural causes (see part 2.1).

After WWII, former affordable work forces left mountains [16] and local people no longer wanted to work in the conditions experienced in the early $20^{\text {th }}$ century. Nevertheless, knowing the more diversified construction techniques, it was time for technical developments. To protect classic dry stone or masonry gravity dams from scouring, concrete foundations were developed in the 1940s [50]. Calculations on reinforced concrete made it possible to design cantilever dams from the 1950s [50]. Some reinforced-concrete check dams were thus built under conservative hypothesis of design. While they are still in good condition, attempts to optimize dam thickness sometimes show disappointing results. New standards on concrete construction and the practical feedback of 30 years helped to develop French standards for check dam management [51].

New solutions also emerged such as open check dams. After the first tests (1950s-1960s) [52], their number exploded (1970s-1980s) [50,51] with the urbanization of alluvial fans. Located near the fan apex, these structures are less expensive than check dams in the headwaters and have a direct effect on exposure of elements at risk. As a consequence, they are preferred in contexts of high stakes. In France, they are considered as temporary sediment retention dams, whereas in other countries, several functions can be assigned to them $[53,54]$. In the same time, channels and embankments were built to limit shifting and to allow dwellings. In such case, check dams allow limiting local incision. Nevertheless, some examples show that they could have negative effect if they are built too high and upstream the fan apex, without any downstream bed protection [8].

\section{Torrential risk management in mountains changed over time}

To mitigate natural risk, French regulations (Fig. 3) and specific organization of mountainous areas (Fig. 4) have been developed since the $19^{\text {th }}$ century. This chapter divides the analysis of these elements into two parts, considering the 1960 s as a turning period.

\subsection{0-1960s: the national RTM policy managed by the Water and Forestry Administration (WFA)}

\subsubsection{From the "forester" lobbying to RTM laws}

In a context of a high risk related to sediment production, the "forester" lobbying advocated a state regulated extensive afforestation of French mountainous massifs [27]. On the one hand, they aimed to protect local elements at risk in mountainous valleys. On the other hand, they expected to reduce distant damage along lowland rivers [14], called the regional scale. After major floods in the 1840 s and 1850 s, the emperor Napoleon III made mountains' afforestation as one of the needed administrative measure to develop public prosperity [55].

The two consecutive laws on reforestation of mountainous areas (28/07/1860) and on grass seeding $(08 / 06 / 1864)$ had extensive objectives. They defined means for achieving the consolidation of mountainous lands. Too ambitious and conflicting with pastoralism uses, their application was mainly limited to the Massif Central and the southern Alps [11]. These first laws were replaced by the law on restoration and conservation of mountainous areas, called RTM law (04/04/1882). Restoration works, declared of public interest, were mandated within a geographic area called "restoration perimeter", where soils were particularly degraded. Unlike the 1860s laws, it doesn't impose technical means. Outside those perimeters, local municipalities and privates could be public funded to consolidate soil and improve pastures. Within areas where degradation of soil was expected in the near future, protective measures to conserve areas and pastures was decreed for ten years. This law was then twice amended: to extend mandatory works to those which maintain and protect soil but also regulate the water flow $(16 / 08 / 1913)$; to simplify the process of public interest statement (06/01/1933).

Taking into account all those RTM laws and according to the geographic location, one or several objectives could be sought [25]:

- At a regional scale, soil consolidation and regulation of water flow aimed to reduce flood risk due to sediment load and peak discharges along lowland rivers. It was based on extensive afforestation of headwaters, which often needed previous biological works (wattling, fascines, brush mattresses, and sods), rustic check dams when stones were available and larger ones in torrents.

- At a local scale, soil restoration aimed to control torrents or avalanche paths hazardous for mountainous population, their crops and networks. At least, they aimed to reduce this local risk. It was based on afforestation and on biological and civil engineering works.

- At a global scale, it's about stabilizing the population in mountainous areas through soil conservation and pastoralism improvement actions (e.g. new cheese cooperatives). 


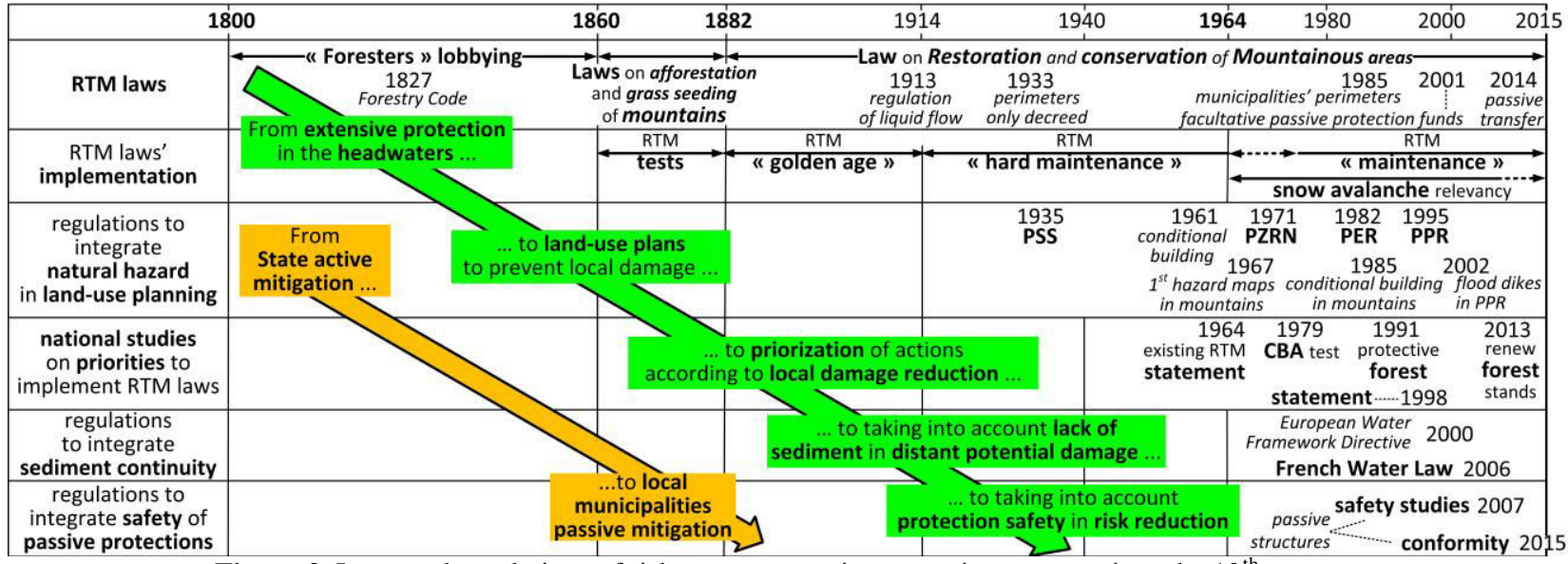

Figure 3. Laws and regulations of risk management in mountainous areas since the $19^{\text {th }}$ century.

\subsubsection{Results of RTM laws implementation by WFA}

The WFA implemented RTM actions from 1860 to 1964 in 25 departments of the mountainous massifs, gathering 28 "special" forestry officers [56]. In 1963, 9 "special" RTM services acted in 12 departments of the Alps and the Pyrenees with 115 special officers [57].

The first WFA action was to help declaring perimeters of public interest and acquiring needed areas. In 1964, 131 perimeters existed for ca. 522000 ha in 25 departments. Almost 380000 ha were acquired by the WFA [11]. Areas acquired were very limited (roughly $13000 \mathrm{ha}$ ) in 7 departments of the Vosges, the Jura and the Massif Central. For 140800 ha over 8 departments of the Mediterranean region, erosion was considerably reduced compared to 1860 . For 226500 ha over 10 departments of the Alps and the Pyrenees $(72 \%$ in the southern Alps), natural phenomena were still active [57]. Acquired areas were limited in the northern Alps notably because of extensive dairy industry. It was also the case in the Pyrenees because of specific social aspects and opposition to heavy State control [58].

Within those areas, a second WFA action consisted in implementing mandatory works: forestry works (afforestation, grass seeding), civil engineering works (e.g. check dams), auxiliary works (e.g. tracks, fences), and needed technical studies [25]. New works were mainly implemented between 1882 and 1914. Then, maintenance works became more significant [10]. Over one century (1860-1964), 200000 ha were reforested in acquired areas (60\% artificially - 40\% spontaneously) and almost 100000 (mainly rustic) check dams were built [5]. In the southern Alps and the Cevennes, extensive forestry works were preferred. In the northern Alps, check dams set up was favored compared to other actions because of limited acquired areas [11]. In the Pyrenees, it was also the case in a very limited area (7 900 ha), until an extreme flood in 1940 in the Pyrénées-Orientales. After this event, extensive afforestation was implemented and acquired areas increased to reach 28700 ha in 1964 [57].

Once new works done, a third action was the maintenance. Forestry one was done by the forestry service whereas the "special" RTM service was in charge of civil engineering structures [57].

A fourth action was to fund facultative works outside RTM perimeters. Such ones were implemented within 35 departments. In 1909, among 247,000 ha of artificially reforested areas at the national scale, $40 \%$ were by local municipalities or privates. In the Massif Central, it was $50 \%$ by privates whereas only $25 \%$ in the Alps. Pastoralism improvements were mainly funded in the Pyrenees (Haute Garonne, Ariège) and in Savoie [25].

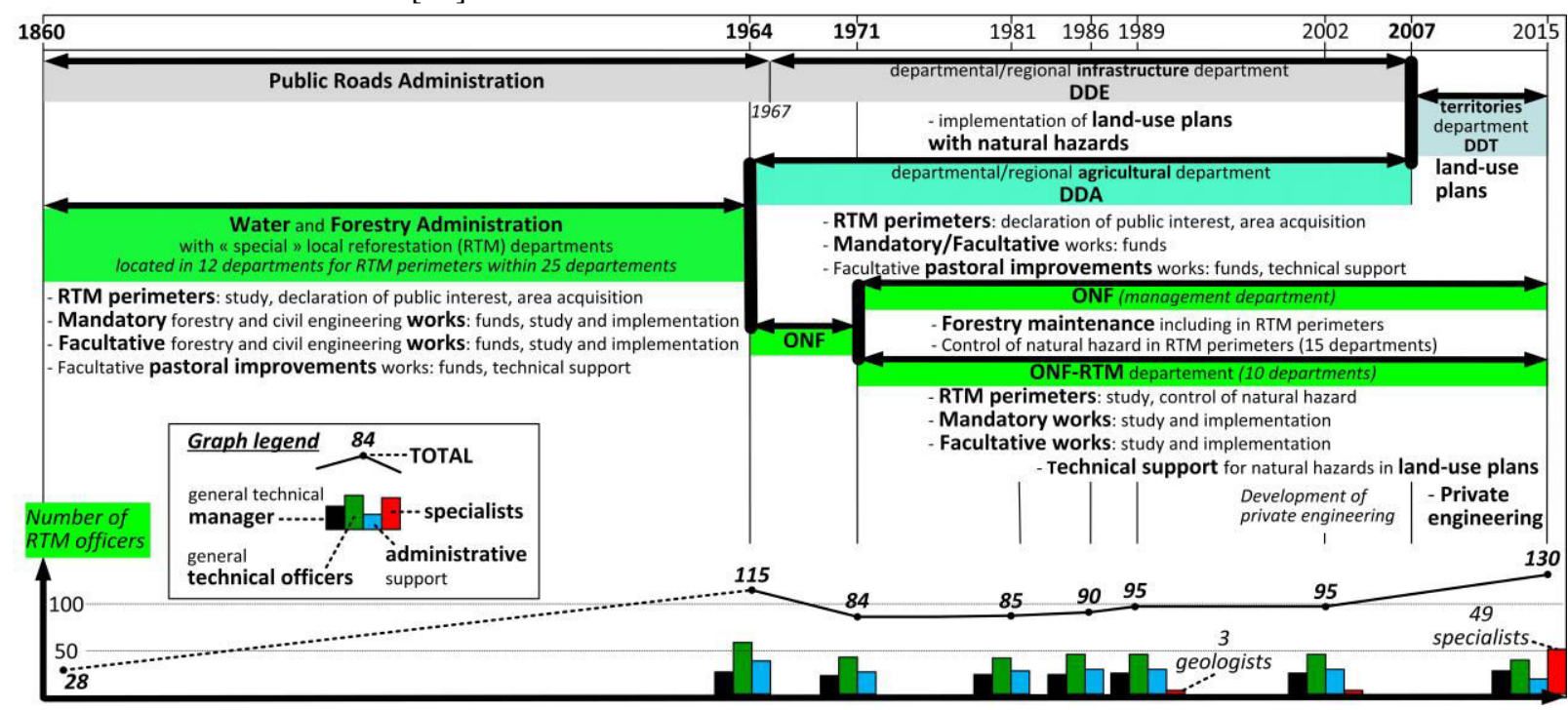

Figure 4. Chronological risk management development in mountainous areas and evolution of the RTM department. 


\subsection{Since the 1960s: the national preventive policy and the RTM department}

\subsubsection{0-1980: new preventive policy advent}

In 1961, a decree first preventively integrated that building was conditionally accepted in natural risk prone areas (30/11/1961). First natural hazard maps were then defined in Isère from 1967 until 1973 [44]. After the 111 casualties in Val d'Isère and the Plateau d'Assy in 1970, plans for areas exposed to natural risk (PZRN, Plan de Zonage des Risques Naturels in French) were created in 1971 and had to be integrated in land-use plans. Following the 1961 decree, articles R111-2 and R111-3 were introduced into the national Urban planning Code in the 1970s: for areas without any land-use plan, a building project has to take into account natural hazards.

As population grew in valleys, the construction of torrential passive protections (embankments, sediment traps) exploded, mainly funded by local municipalities. Snow avalanche risk became significant, and civil engineering protections were developed as RTM mandatory and facultative works [59]. During this period, maintenance of RTM torrential active protections was neglected [57] and questions raised about priorities of public RTM funds [45].

In parallel, the WFA organization was changed, separating the ONF from the agricultural administration $(23 / 12 / 1964$ law). For the former, the new management departments had to implement the forestry regime in public forests. After an adjustment period and a reduction of specific workforces, the ONF-RTM department was created in 1971 under the direction of Messines Paviot du Sourbier with 84 public officers [60]. From this period, a new public organization implemented RTM laws [57]:

- ONF: management of existing forests taking into account their protective function; control of natural hazard activity in the 15 departments with RTM perimeters but without a RTM department;

- DDA (agricultural departmental administration): implementation of pastoral improvements and responsible of funds for mandatory and facultative works. - ONF-RTM: technical interlocutor of DDA in 10 RTM departments: control of natural activity in RTM perimeters; control, maintenance, design and construction of structures; specialist partner for developing preventive actions in mountainous areas and for building passive protections by local municipalities. 1980-2007: development of local prevention management and regulation

From the 1980s, the national policy of risk management evolved and local prevention, managed by the DDE (infrastructure departmental administration), became the main issue. PZRN turned into PER (Plan d'Exposition aux Risques in French) (13/07/1982 law) and then PPRN (Plan de Prévention des Risques Naturels in French) (02/02/1995 law). In the meanwhile, an innovative national insurance system called CatNat (1882 law), was created in order to compensate individual losses after catastrophic events. According to the "mountain" law (09/01/1985), mountainous hazards must have been integrated in any building plan. Finally, a national preventive fund against natural hazard (Fonds Barnier) was created (1995 law).

From the 1960s, environment started to become a significant topic for civil society, as evidenced by the French Water Laws (16/12/1964, 04/01/1992, $30 / 12 / 2006)$. The latter is the transposition of the European Water Framework Directive (23/10/2000), which first integrated the issue of sediment continuity. Since 2000, regulations aimed to improve water habitats [42] and to limit downstream incision damage [43].

From the 1980s, RTM actions refocused on local protection and studies helped to state on maintenance actions of existing protections [10]. The first Cost-Benefit Analysis (CBA) was tested in Savoie (the Maurienne valley) in 1979 [61]. The local benefits due to the protective role of public forests were studied in 1991 [62]. The protective role of forest and civil engineering structures in RTM perimeters was described in 1998.

As a consequence of this local management of protective actions, two new laws amended RTM laws for an increasing role of local municipalities and of passive protections. From this, local municipalities can manage a new RTM perimeter (09/01/1985 law). Also, passive protections can be considered as facultative works funded by the national RTM policy (09/07/2001 law).

Following those developments, the ONF-RTM missions evolved. In 1981, their participation for the establishment of preventive plans was officially acted and 3 new geologists were integrated in 1989 [63]. In parallel, private expertise increased, helping to develop private or public local protective structures outside RTM perimeters. For 30 years (1971-2002), the ONF-RTM organization has not significantly evolved (Fig. 4) [63].

\subsubsection{Since 2007: towards safety, effectiveness and dependability in risk prevention policy}

On the one hand, local municipalities can be responsible of passive structures' maintenance (dikes, sediment retention basins) whatever their owners $(27 / 01 / 2014$ and $07 / 08 / 2015$ laws). On the other hand, mandatory structures built according to RTM laws have always been maintained by the French government. More than 21000 civil engineering structures are currently controlled, among them, more than 14000 check dams [11]. The ONF maintains protective RTM forests.

The distant effects on sediment continuity and incision risk became a design and maintenance subject (30/12/2006 law). Moreover, passive flood protections first need hazard studies (11/12/2007 decree) and must be legally brought into conformity to be effective, dependable and safe (12/05/2015 decree). RTM check dams are also maintained according to their effectiveness expertly assessed [6]. In the same way as in 1991 [62], a new survey has been engaged since 2012 to establish the protective effect of RTM forests and to decide the renewal of priorities. These evolutions trend to a risk quantification including effect of protections, distant damage, and protection failures. This needs special skills. 
To encourage and control all these policy evolutions, local administration was reorganized in 2007. The DDT (departmental administration of territories) locally represents both the Ministry of Agriculture (former DDA) and the Ministry of Environment (former DDE). At the same time, the ONF-RTM missions have evolved [64] to be an expert service helping DDTM to implement RTM laws, save pastoralism improvements, and the risk prevention policy in mountains. It is also a technical adviser for local municipalities through private engineering. ONF-RTM organization has thus evolved to reach 130 officers in 2014 [65] integrating special profiles: geologist, geotechnical, hydraulics, civil and avalanche engineers, designers.

\section{Protections: specifying objectives and functions to maintain them}

Forest and civil engineering structures have been implemented to mitigate torrential risk for more than 150 years. Even if risk quantification is difficult, current maintenance decisions must be based on expert risk analysis. As a first step to move towards this goal, this part qualitatively synthesizes objective, function and expected effect of existing protections.

\subsection{Analysing objectives and potential effect at several decision scales to help decision}

From the previous parts, it's a fact that there are two scales of physical influence: the local scale is almost the torrential watershed; the regional scale is the general fluvial system from torrential river to lowlands' river. Protection objectives are different according to these scales and have changed over time. For instance, the initial objective could be to curtail sediment production to protect local exposed elements such as a housing area, whereas current legal objective is to maintain sufficient sediment continuity from the headwaters to lowlands.

Risk analysis is increasingly needed to help maintenance decisions. Analyzing protection objectives helps to specify what the expected effect on risk mitigation was. Comparing it with current situation can help assessing its effectiveness [6].

Nevertheless, more than 150 years of experience show that other effects, such as economic but also environmental, damage due to a distant incision for instance, eventually occur. Torrential hazard has thus evolved to a multi-issues hazard integrating hydro-system quality. This paper allowed better identifying potential effect of protections on torrential processes at those different scales. Moreover, structural failures may also occur and can have unexpected consequences such as increasing the sediment release [8].

Expected mitigation effects, potential unexpected effects and potential failure of torrential protections should be thus integrated in risk reduction analysis. For the former, three main historical objectives have been extracted from our analysis to explain what was expected from torrent control works (see part 3.1.1) at local and regional scales.

To help deciding on maintenance actions, the general following framework of analysis, based on the principle of decision-aid methods taking into account risk reduction such as the Cost-Benefit Analysis (CBA), can be proposed [6]. A first task is to choose the referent (baseline) situation. We assume a stationarity hypothesis in the hazard process. Existing protections have a current structural and functional condition. Maintenance to this condition level can be considered as a baseline situation (A0). We consider other potential alternatives: artificial destruction (A1), voluntary abandonment (A2) or rehabilitation to increase the condition level (A3).

1.1. Elements at risk analysis and assessment taking into account economic, environmental or other damage:

a. without current elements at local risk and no expected future increase, possible alternatives could be $\mathrm{A} 1$ or $\mathrm{A} 2$;

$b$. with current elements at risk or expected future ones, A0 or A3 should be potential alternatives;

c. elements at risk, including hydro-system quality, at regional scale due to sediment load (excess or lack) must be also specified.

1.2. Local hazard analysis must be performed for each alternative, only in presence of elements at risk (1.1.b). With A1 and A2, a hazard increase is eventually to be expected, whereas hazard stabilization can be expected with A0. Local risk is analyzed taking into account results of step 1.1.b.

1.3. Regional hazard analysis related to sediment load is more complicated than in the $19^{\text {th }}$ century: while excess sediment load in rivers may still be a problem in some rivers, the opposite case, i.e. chronic sediment deficits, also emerge during the $20^{\text {th }}$ century (Fig. $2 \& 3$ ). Consequently, regional risk may refer to both situations and must be analyzed for each alternative (for cases 1.1.a. and 1.1.b.). Considering A1 and A2, if sediment-load deficit has to be prevented, a hazard decrease should be planned, whereas with A0 or A3, hazard maintenance or increase should be expected (inversely if sediment load excess has to be prevented). Regional risk is analyzed taking into account results from step 1.1.c. Overall, some contradictory situations will surely occur with local sediment excess and distant sediment lack. Large scale watershed studies, highlighting the best suited sediment source reactivation operations, may be a solution in this kind of situation [67].

1.4. Global risk and risk difference with baseline situation A0 can be analyzed for each alternative taking into account risk analysis from 1.2. and 1.3.

1.5. Cost analysis must be performed for each alternative to be compared with global risk difference, using an efficiency indicator.

In this framework, first specifying the initial objective (case 1 or case 2), can help analyzing the initial expected effect on hazard. It thus can help analyzing current hazard evolution according to alternatives in steps 1.2. and 1.3. In parallel, analyzing objective changes over time can also help analyzing protective effectiveness evolution. 


\subsection{Synthesis of potential functions of torrential protections}

Several protection technics have been implemented to achieve a given objective: e.g., reducing regular sediment load, increasing flood submersion, reducing brief or intense hyper-concentrated events. These objectives were dependant on the torrential process. To achieve them, several structures have specific functions to act on sediment production and transfer.

Specifying these functions help a better analysis of expected effects of existing check dams on torrential process, and then non-expected effects. Moreover, considering the functional failure as the no achievement of a given function, it helps to specify their potential failures. Specifying functions of existing protection is thus the first step to implement the previous decision-aid framework (see part 4.1).

For this purpose, a list of potential functions for the main torrential protection technics described throughout this paper can be drawn. Elements are extracted from the previous historical analysis (see part 2), completed by the corresponding detailed paper on check dams [8], a detailed international analysis of open check dams $[53,54]$, on the RTM database, on the Austrian standard to maintain torrential protection structures [68] and on the French technical manual to manage protective forests in the Alps [69]. We also propose scale of capacity assessment which is the measurable ability related to a function [4]. Indeed, it is needed to quantify the protective effect on hazard and related risk [8].

Torrent control works typically consist in implementing structural measures such as protection forests, check dams, open check dams, dykes and bank protection. Table 1 gathers and summarizes the varied functions and expected effects on torrent hazard ensured by these structures. The measurement of the function is given as well as the main parameters influencing the capacity. Obviously, some parameters influence the capacity whatever the functions, such as vegetation type and stage of development for protection forest; check dams' shapes, sizes and locations or open check dams' types, size of openings and basin features. These somewhat universal parameters are thus not repeated at each table line for the sack of conciseness.

\section{Conclusion}

This historical analysis shows that torrential floods are related to lowlands' floods through sediment transport and continuity. At a local scale, sediment deposition directly threatens elements at risk. Numerous active protection works have been implemented since the $19^{\text {th }}$ century to protect local and regional areas from hazard related to sediment production and transport from the headwaters.

According to the RTM laws, the French government must maintain and renew ageing protective structures implemented in a changing context. Torrential flood hazard changed along with general climate change, human activity in the headwaters, natural and artificial revegetation. Population in mountains has changed and exploded on alluvial fans or decreased according to the geographic location. Mitigation measures evolved from the unique protection in the headwaters managed by the State (with local and regional objectives according to the geographic location), to local land-use planning and protection in alluvial fans (managed by the local municipalities). The public RTM service organization evolved to help this preventive policy in mountainous areas. As a consequence, the global preventive budget against torrential floods, initially devoted to torrential protection, has been partitioned to implement all these different mitigation actions. Regulatory constraints increased with multi-issues to achieve. New effectiveness, safety, dependability and risk reduction concepts must now be taken into account to decide maintenance actions.

To help to maintain protective structures, this paper gives also some methodological elements based on a global risk analysis taking into account the expected effects, the unexpected effects, as well as the failure consequences. A first key step is detailed introducing potential functions for main types of torrential protection. To implement those decision steps, a lot of scientific and operational gaps remain to be closed. First, specifying the local functional capacity is based on several field indicators and criteria imperfectly assessed. In the same way, their structural capacity assessment, which is their capacity of structural resistance to natural events, is also based on imperfect information. Second, once causes and consequences on capacity of failure are assessed, their probability has to be specified, conditionally to natural hazard. Third, the quantitative effect of protective structures, and of their potential maintenance actions, has to be assessed at local and regional scales. It is actually based on an expert assessment which can take into account several sources of information (numerical models, physical models, geomorphic assessment, etc.). Fourth, exposed elements have to be defined but also assessed at several scales. Their vulnerability, which depends on the intensity of phenomena, is a key knowledge, but imperfect, to assess potential damage according to previous hazard assessment. Fifth, the cost is also a key criterion to decide, but remains imperfect in mountainous context where cost of works is very sensitive to conditions of supply and safety.

\section{Acknowledgments}

This study was funded by Irstea, the French Agricultural and Forest Ministry, the French Environment Ministry. 


\begin{tabular}{|c|c|c|c|c|}
\hline Measure & Function & Capacity & Parameter & Expected effects \\
\hline \multirow{4}{*}{$\begin{array}{l}\text { Protection } \\
\text { forest } \\
\text { influence } \\
\text { on torrent } \\
\text { hazards }\end{array}$} & $\begin{array}{l}\text { To maintain } \\
\text { sediment on } \\
\text { mountainous } \\
\text { hillslopes }\end{array}$ & $\begin{array}{l}\text { Maximal volume of } \\
\text { potential releasing } \\
\text { sediment maintained on } \\
\text { hillslopes }\end{array}$ & $\begin{array}{l}\text { Area of potential erosion } \\
\text { covered; the potential } \\
\text { erosion depth according to } \\
\text { geomorphic criteria }\end{array}$ & $\begin{array}{l}\text { Reducing regular } \\
\text { sediment production } \\
\text { and sediment load at } \\
\text { local and regional } \\
\text { scales }\end{array}$ \\
\hline & To limit run-off & $\begin{array}{l}\text { Maximal water volume } \\
\text { absorption }\end{array}$ & $\begin{array}{l}\text { Time interval between rain } \\
\text { events, rain intensity, soil } \\
\text { characteristics, and covered } \\
\text { soil area }\end{array}$ & $\begin{array}{l}\text { Reducing the peak } \\
\text { liquid flow mainly at } \\
\text { regional scale }\end{array}$ \\
\hline & $\begin{array}{l}\text { To stop block } \\
\text { propagation in } \\
\text { rock fall paths }\end{array}$ & $\begin{array}{l}\text { Maximal global volume of } \\
\text { blocks maintained on } \\
\text { hillslopes }\end{array}$ & Blocks' volumes & $\begin{array}{l}\text { Reducing supply to the } \\
\text { torrent bed, potentially } \\
\text { recruited by debris } \\
\text { flow events. }\end{array}$ \\
\hline & $\begin{array}{l}\text { To punch the } \\
\text { snowpack in } \\
\text { release zone of } \\
\text { avalanche paths }\end{array}$ & $\begin{array}{l}\text { Maximal potential } \\
\text { releasing volume of snow } \\
\text { maintained }\end{array}$ & $\begin{array}{l}\text { Slope and possible upslope } \\
\text { uncontrolled areas (cliffs, } \\
\text { glaciers) }\end{array}$ & $\begin{array}{l}\text { Reducing the volume } \\
\text { of avalanche and the } \\
\text { related potential wood } \\
\text { and sediment supply }\end{array}$ \\
\hline \multirow{5}{*}{$\begin{array}{l}\text { Check } \\
\text { dams }\end{array}$} & $\begin{array}{l}\text { To stabilize } \\
\text { torrent beds }\end{array}$ & $\begin{array}{l}\text { Sediment volume } \\
\text { stabilized by the structure } \\
\text { against incision and bank } \\
\text { erosion (on the long term) }\end{array}$ & $\begin{array}{l}\text { Geology, potential erosion } \\
\text { depth, valley } \\
\text { geomorphology }\end{array}$ & $\begin{array}{l}\text { Decrease diffuse } \\
\text { sediment production on } \\
\text { the long term, facilitate } \\
\text { vegetation settling }\end{array}$ \\
\hline & $\begin{array}{l}\text { To consolidate } \\
\text { hillslopes }\end{array}$ & $\begin{array}{l}\text { Decrease in supply volume } \\
\text { due to the landslide or rock } \\
\text { avalanche }\end{array}$ & $\begin{array}{l}\text { Geology, geometrical and } \\
\text { geotechnical features of the } \\
\text { mass movement, } \\
\text { hydrogeology. }\end{array}$ & $\begin{array}{l}\text { Stop massive sediment } \\
\text { supply from a key } \\
\text { nearly unlimited source }\end{array}$ \\
\hline & $\begin{array}{l}\text { To decrease bed } \\
\text { slope }\end{array}$ & $\begin{array}{l}\text { Decrease in sediment } \\
\text { transport capacity (bulk } \\
\text { discharge and boulder } \\
\text { recruitment) }\end{array}$ & $\begin{array}{l}\text { Hydrology, sediment supply, } \\
\text { bed and transported grain } \\
\text { size distributions }\end{array}$ & $\begin{array}{l}\text { Prevent massive } \\
\text { instantaneous sediment } \\
\text { and huge boulder } \\
\text { transport }\end{array}$ \\
\hline & $\begin{array}{l}\text { To durably } \\
\text { retain materials }\end{array}$ & $\begin{array}{l}\text { Maximum sediment } \\
\text { volume trapped by the } \\
\text { structure }\end{array}$ & $\begin{array}{l}\text { Volume to retain, geometry } \\
\text { of the valley. }\end{array}$ & $\begin{array}{l}\text { Short term trapping of } \\
\text { the sediment load }\end{array}$ \\
\hline & $\begin{array}{l}\text { To regulate } \\
\text { sediment } \\
\text { transport }\end{array}$ & $\begin{array}{l}\text { Mean transient volume of } \\
\text { sediment storage buffering } \\
\text { upstream supply. }\end{array}$ & $\begin{array}{l}\text { Frequency and magnitude of } \\
\text { the sediment supply, length } \\
\text { between structures, type of } \\
\text { sediment transport process }\end{array}$ & $\begin{array}{l}\text { Diminution of the } \\
\text { number of intense } \\
\text { sediment transport } \\
\text { events. }\end{array}$ \\
\hline \multirow{4}{*}{$\begin{array}{l}\text { Open } \\
\text { check } \\
\text { dams }\end{array}$} & $\begin{array}{l}\text { To store an event } \\
\text { sediment volume }\end{array}$ & $\begin{array}{l}\text { Maximum sediment } \\
\text { volume trapped by the } \\
\text { structure and subsequently } \\
\text { dredged. }\end{array}$ & Volume to retain & $\begin{array}{l}\text { Flood scale total } \\
\text { trapping of sediment } \\
\text { supply }\end{array}$ \\
\hline & $\begin{array}{l}\text { To sort } \\
\text { undesirable } \\
\text { transported } \\
\text { material }\end{array}$ & $\begin{array}{l}\text { Change in the size and } \\
\text { quantity of coarse } \\
\text { material: woody debris } \\
\text { and/or boulders. }\end{array}$ & $\begin{array}{l}\text { Type and size of material to } \\
\text { sort (woody debris and/or } \\
\text { boulders). }\end{array}$ & $\begin{array}{l}\text { Trapping of material } \\
\text { that aggravate flood } \\
\text { transfer downstream : } \\
\text { long logs and boulders }\end{array}$ \\
\hline & $\begin{array}{l}\text { To dose peak } \\
\text { flow }\end{array}$ & $\begin{array}{l}\text { Decrease in the } \\
\text { instantaneous peak } \\
\text { discharge (water or } \\
\text { sediment) }\end{array}$ & $\begin{array}{l}\text { Type of phenomena } \\
\text { (bedload, debris flood, } \\
\text { debris flows) }\end{array}$ & Lower peak discharges \\
\hline & $\begin{array}{l}\text { To break debris } \\
\text { flows energy }\end{array}$ & $\begin{array}{l}\text { Number of trapped coarse } \\
\text { granular debris flow front }\end{array}$ & $\begin{array}{l}\text { Size of transported boulders, } \\
\text { typical number of surges. }\end{array}$ & $\begin{array}{l}\text { Lower channel erosion } \\
\text { and better transfer due } \\
\text { to less 'surggy' debris } \\
\text { flows }\end{array}$ \\
\hline Dyke & $\begin{array}{l}\text { To keep flow in } \\
\text { a chosen path }\end{array}$ & $\begin{array}{l}\text { Maximum contained event } \\
\text { magnitude }\end{array}$ & $\begin{array}{l}\text { Type of phenomena, flood } \\
\text { height. }\end{array}$ & $\begin{array}{l}\text { Lower frequency of } \\
\text { flooding }\end{array}$ \\
\hline $\begin{array}{l}\text { Bank } \\
\text { protection }\end{array}$ & $\begin{array}{l}\text { To keep flow in } \\
\text { a chosen path } \\
\text { without lateral } \\
\text { erosion }\end{array}$ & $\begin{array}{l}\text { Length and depth of bank } \\
\text { protected }\end{array}$ & $\begin{array}{l}\text { Type of phenomena, flood } \\
\text { height. }\end{array}$ & Lower lateral erosion \\
\hline
\end{tabular}

Table 1: Synthesis of structural measure functions, capacity and expected effects. 


\section{References}

[1] Ledoux B. (2006). La gestion du risque inondation.

[2] Meunier M. (1991). Eléments d'hydraulique torrentielle.

[3] Courtray V. (2013). Prevention of natural hazards in mountain areas. Proceedings of the 29th session EFC/FAO Working Party.

[4] Tacnet J.-M. ed. (2012). Decision Support Guidelines. Methods, procedures and tools, PARAmount (WP7).

[5] Messines du Sourbier J. (1964). Enquête sur la conservation et la restauration des terrains en montagne, Administration des Eaux et Forêts.

[6] Carladous s., Tacnet J.-M., Eckert N., Curt C. and Batton-Hubert M. (2014). Vers une analyse intégrée de l'efficacité des ouvrages de protection contre les risques naturels en montagne : évaluation économique en complément des volets structurels et fonctionnels. Proceedings of the 8th JFMS Conference, pp. 61-74.

[7] Philippe F., Tacnet J.-M. and Carladous S. (2015). La prise en compte des ouvrages de protection contre les phénomènes torrentiels dans les PPR: Etat des lieux et analyse critique des pratiques récentes dans les départements de montagne de France métropolitaine, irstea.

[8] Piton G., Carladous S., Recking R., Tacnet J.-M., Liébault F., Kuss D., Quefféléan Y. and Marco O. (sub. to). Why do we build check dams? An historical perspective from the French experience. Earth Surface Processes and Landforms.

[9] Tacnet J.-M., Dezert J., Curt C., Batton-Hubert M. and Chojnacki E. (2014). How to manage natural risks in mountain areas in a context of imperfect information? New frameworks and paradigms for expert assessments and decision-making. Environment Systems and Decisions, 34(2), pp. 288-311.

[10] Brugnot G. and Cassayre Y. (2002). De la politique française de restauration des terrains en montagne à la prévention des risques naturels. Proceedings of the Conf. Les pouvoirs publics face aux risques naturels dans l'histoire.

[11] Carladous S., Piton P., Tacnet J.-M., Philippe F., Nepote-Vesino R., Quefféléan Y. and Marco O. (2016). From the restoration of French mountainous areas to their global management: historical overview of the Water and Forestry Administration actions in public forests. Proceedings of the 13th Interpraevent Congress.

[12] Tacnet J.-M. and Degoutte G. (2013). Chapter 5 Principes de conception des ouvrages de protection contre les risques torrentiels in Torrents et rivières de montagne : Dynamique et aménagement. pp. 267-331.

[13] MEDDE-CGDD (2014). Analyse multicritères des projets de prévention des inondations. Guide méthodologique.
[14] Kalaora B. and Savoye A. (1986). La forêt pacifiée. Sylviculture et sociologie au XIXe siècle. [In French].

[15] de Crécy L. (1983). Evolution de la RTM de 1860 à 1983. La politique de prévention des risques naturels en montagne depuis 150 ans. Proceedings of the 108th national Conf. of Sociétés savantes. [In French].

[16] Van Effenterre C. (1982). Les barrages perméables de sédimentation. Revue Forestière Française, 5 , pp. 87-93.

[17] Liébault F. and Taillefumier F. (2000). The contemporary development of the active tract of the main tributaries of the Drôme, the Eygues and the Roubiuon, in the southern pre-Alps of France. Géocarrefour, 75(4), pp. 327-336.

[18] Flez C. and Lahousse P. (2014). Recent Evolution of Natural Hazard Management Policy in France, the Example of Serre-Chevalier (French Alps). Environmental Management, 34(3), pp. 353-362.

[19] ONF-RTM 38 (2014). Torrent de la Grollaz Etude de bassin versant.

[20] Comiti F. (2012). How natural are Alpine mountain rivers? Evidence from the Italian Alps. Earth Surface Processes and Landforms, 37, pp. 693-707.

[21] Gras S. (1857). Etudes sur les torrents des Alpes.

[22] Valles F. (1857). Etudes sur les inondations: leurs causes et leurs effets. Les moyens à mettre en ouvre pour combattre leurs inconvénients et profiter de leurs avantages.

[23] Liébault F., Gomez B., Page M., Marden M., Peacock D., Richard D. and Trotter C.M. (2005). Land-use change, sediment production and channel response in upland regions. River Research and Applications, 21, pp. 739-756.

[24] Bravard J.-P., Amoros C., Pautou G., Bornette G., Bournaud M., Creuzé des Châtelliers M.,Gibert J., Peiry J.-L., Perrin J.-F. and Tachet H. (1997). River incision in South-East France: morphological phenomena and ecological effects. Regulated Rivers: Research \& Management, 13(3), pp. 75-90.

[25] Direction générale des eaux et forêts (1911). Restauration et conservation des terrains en montagne - Trois parties.

[26] Mougin P. (1931). La restauration des Alpes.

[27] Surell A. (1841). Etude sur les torrents des Hautes Alpes.

[28] Champion M. (1856). Recherches historiques sur les inondations du Rhône et de la Loire.

[29] Jouyne Z. (1850). Reboisement des montagnes: Reboisement, difficultés, causes des inondations et moyens de les prévenir.

[30] Fabre J.-A. (1797). Essai sur la théorie des torrens et des rivières.

[31] Gras S. (1848). Considérations sur les anciens lits de déjection des torrents des Alpes et sur leur liaison avec le phénomène erratique.

[32] Gras S. (1850). Exposé d'un système de défense des cours d'eau torrentiels des Alpes et 
application au torrent de la Romanche dans le département de l'Isère.

[33] Breton P. (1867). Mémoire sur les barrages de retenue de graviers dans les gorges des torrents.

[34] Demontzey P. (1882). Traité pratique du reboisement et du gazonnement des montagnes.

[35] Kuss C. (1900). Restauration et conservation des terrains en montagne. Les Torrents glaciaires.

[36] Kuss C. (1900). Restauration et conservation des terrains en montagne. Éboulements, glissements et barrages.

[37] Bernard C. (1900). Restauration et conservation des terrains en montagne: Les Terrains et les paysages torrentiels (Haute-Savoie).

[38] Mougin P. (1931). La restauration des Alpes.

[39] Mougin P. (1914). Les torrents de Savoie.

[40] Bernard B. (1927). Cours de restauration des montagnes.

[41] Petit F., Poinsart D. and Bravard J.-P. (1996). Channel incision, gravel mining and bedload transport in the Rhône river upstream of Lyon, France ('canal de Miribel'). Catena, 26(3), pp. 209-226.

[42] Braud S. and Alber A. (2013). Synthèses et connaissances \& proposition d'une méthode d'évaluation de l'impact des ouvrages transversaux sur la continuité sédimentaire des cours d'eau, DREAL Centre.

[43] Brochot S., Duclos P. and Bouzit M. (2003). L'évaluation économique des risques torrentiels: intérêts et limites pour les choix collectifs de prévention. Ingénieries, Spécial, pp. 53-68.

[44] Besson L. (1985). Les risques naturels. Revue de géographie alpine, 73(3), pp. 321-333.

[45] Commandeur M. (1979). Coûts et avantages des travaux RTM - Cas d'une zone urbanisée. Thèse UER de Géographie de Grenoble.

[46] Coussot P. (1992). Rhéologie des boues et laves torrentielles. Etudes de dispersions et suspensions concentrées. Thèse Université Joseph Fourier de Grenoble.

[47] Thiéry E. (1891). Restauration des montagnes, correction des torrents, reboisement.

[48] Mougin P. (1900). Restauration et conservation des terrains en montagne - consolidation des berges par dérivation d'un torrent (torrent de Saint Julien).

[49] Lenoble F. (1923). La légende du déboisement des Alpes. Revue de géographie alpine, 11, pp. 5-116.

[50] Poncet A. (1995). Restauration et conservation des terrains en montagne - 10 fascicules.

[51] Deymier D., Tacnet J.-M. and Mathys N. (1995). Conception et calcul de barrages de correction torrentielle.

[52] Ferro V. (2013). Modern Strategies for Torrent Control: Slit and W-Weir Check Dams in Check Dams, Morphological Adjustments and Erosion Control in Torrential Streams, pp. 33-62.

[53] Piton G. and Recking a. (2015). Design of sediment traps with open check dams: a review, part I: hydraulic and deposition processes. Journal of Hydraulic Engineering, pp. 1-23.
[54] Piton G. and Recking A. (2015). Design of sediment traps with open check dams: a review, part II: woody debris problems. Journal of Hydraulic Engineering, pp. 1-17.

[55] Bravard J.-P. (2002). Le "traitement" des versants dans le département de la Drôme: Des inondations de 1840 à la loi du 27 juillet 1860. Annales des ponts et chaussées, pp. 37-43.

[56] Vicaire H. (1861). Circulaire $n^{\circ} 806$ du ler juin 1861 relative à la notification d'un décret impérial portant règlement d'administration publique pour l'exécution de la loi du 28 juillet 1860, relative au reboisement des montagnes, Ministère des Finances - DGF.

[57] Messines du Sourbier J. (1970). Projet de réorganisation des services spéciaux RTM de l'ONF, ONF / DNRN-RTM.

[58] Fesquet F. (1997). Un corps quasi-militaire dans l'aménagement du territoire: le corps forestier et le reboisement des montagnes méditerranéennes en France et en Italie aux XIX et XXèmes siècles. Thèse Université Paul Valéry de Montpellier.

[59] MI and MA (1979). Circulaire interministérielle $n^{\circ} 3005$ du 10 janvier 1979 relative à la RTM, Ministères de l'Intérieur \& de l'Agriculture.

[60] MA (1971). Circulaire ministérielle $n^{\circ} 1272$ du 27 mai 1971: Rapports entre l'Administration et l'ONF, Ministère de l'Agriculture.

[61] R.C.B. (1983). Etude pour l'amélioration des actions de RTM - Approche patrimoniale de la gestion de la sécurité et de la qualité du milieu physique en montagne, Ministère de l'Agriculture.

[62] Sonnier J. (1991). Analyse du rôle de protection des forêts domaniales de montagne. Revue forestière française, 43(2), pp. 131-146.

[63] MA (1972, 1976, 1981, 1986, 1988, 1989, 2000, 2001, 2012). Conventions générales entre l'Etat et l'ONF relative à la $R T M$.

[64] ONF (2007). Instruction $n^{\circ}$ INS-07-T-62 du 26 janvier 2007 relative aux missions, l'organisation des services RTM et la gestion des terrains domaniaux RTM.

[65] ONF (2013). Liste des personnels DERN - RTM au 31/12/2013.

[66] Andréassian V. (2004). Waters and forests: from historical controversy to scientific debate. Journal of Hydrology, 291, pp. 1-27.

[67] Liébault F., Clément C., Piégeay H. and Zahnd E. (2010). Gestion du risque ou gestion de l'environnement? Le cas des massifs du Diois et des Baronnies, Préalpes du Sud, France. Risques et territoires, Interroger et comprendre la dimention locale de quelques risques contemporains, pp. 47 57.

[68] Suda J. (2013). Schutzbauwerke der Wildbachverbauung - Handbuch zur Durchführung einer Bauwerkskontrolle, Lebensministerium.

[69] Ladier J., Rey F. and Dreyfus P., eds. (2012). Guide de Sylviculture de Montagne - Alpes du Sud françaises. 